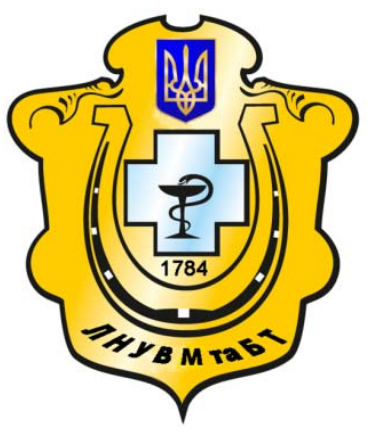

Науковий вісник Львівського національного університету ветеринарної медицини та біотехнологій імені С.3. Гжицького

Scientific Messenger of Lviv National University of Veterinary Medicine and Biotechnologies named after S.Z. Gzhytskyj

doi:10.15421/nvlvet6811

ISSN 2413-5550 print

ISSN 2518-1327 online

$\underline{\text { http://nvlvet.com.ua/ }}$

УДК 637.236

\title{
Дослідження процесів ферментації та фізичного визрівання вершків у весняно-літній період року при виробництві масла 3 пробіотичними властивостями
}

\author{
Л.Я. Мусій, О.Й. Цісарик \\ musiyluba@ukr.net, tsisaryk_o@yaoo.com \\ Львівський національний університет ветеринарної медицини та біотехнологій імені С.3. Гжицького, \\ вул. Пекарська, 50, м. Львів, 79010, Украӥна
}

\begin{abstract}
Метою досліджень було встановити та обтрунтувати оптимальні параметри ферментаиії та фізичного визрівання вершків при виробництві кисловершкового масла у весняно-літній період року за поєднання класичних для масла змішаних мезофільних культур Flora Danica (FD) - Lactococcus lactis ssp. cremoris, Lactococcus lactis ssp. lactis, Leuconostoc mesenteroides ssp. cremoris, Lactococcus lactis ssp. diacetylactis iз термофільною монокультурою Lactobacillus acidophilus пробіотичного штаму La-5 (La-5). Було виготовлено чотири групи кисловершкового масла. У заквашених вериках контролювали активність кислотоутворення за зміною титрованої і активної кислотності та кислотність плазми.

Встановлено можливість поєднання класичних змішаних мезофільних культур FD з термофільною монокультурою L. acidophilus пробіотичного штаму La-5 за ферментачії вериків у технології кисловершкового масла з пробіотичними властивостями. Експериментально встановлено дозу інокуляиії і раціональне співвідношення між FD $i$ La-5 у складi заквашувальної композииії безпосереднього внесення - 1: 1 при вихідній кониентрації кожної культури у вершках $1 \cdot 10^{6}$ КУО/см ${ }^{3}$ для виробництва кисловершкового масла з пробіотичними властивостями. Встановлено параметри процесу ферментачії та фізичного визрівання вершків за поєднання заквашувальних культур FD та La-5 у весняно-літній період року: температура ферментації $(30 \pm 1){ }^{\circ} \mathrm{C}$, тривалість 4 год.; температура фізичного визрівання $(5 \pm 1){ }^{\circ} \mathrm{C}$, тривалість 6 год.

Ключові слова: кисловершкове масло, Flora Danica, L. acidophilus La-5, технологія, ферментація, фізичне визрівання.
\end{abstract}

\section{Исследование процессов ферментации и физического созревания сливок в весенне-летний период года при производстве масла с пробиотическими свойствами}

\author{
Л.Я. Мусий, О.Й. Цисарык \\ musiyluba@ukr.net, tsisaryk_o@yaoo.com
}

Львовский национальный университет ветеринарной медицины и биотехнологий имени С.3. Гюсицкого, ул. Пекарская, 50, г. Львов, 79010, Украина

\begin{abstract}
Целью исследований было установить и обосновать оптимальные параметры ферментации и физического созревания сливок при производстве кислосливочного масла в весенне-летний период года при сочетании классических для масла смешанных мезофильных культур Flora Danica (FD) - Lactococcus lactis ssp. cremoris, Lactococcus lactis ssp. lactis, Leuconostoc mesenteroides ssp. cremoris, Lactococcus lactis ssp. diacetylactis c термофильной монокультурой Lactobacillus acidophilus nробиотического шттамма La-5 (La-5). Было изготовлено четыре группы кислосливочного масла. В заквашенных сливках контролировали активность кислотообразования за изменением титруемой и активной кислотності, а также кислотность плазмы.

Установлена возможность сочетания классических смешанных мезофильных культур FD с термофильной монокультурой L. acidophilus пробиотического штамма La-5 при ферментации сливок в технологии кислосливочного масла с про-
\end{abstract}

\section{Citation:}

Musiy, L.Y., Tsisaryk, O.Y. (2016). Study of the cream fermentation and physical maturation in the spring-summer period under the production of butter with probiotic properties. Scientific Messenger LNUVMBT named after S.Z. Gzhytskyj, 18, 2(68), 56-62. 
биотическими свойствами. Экспериментально установлено дозу инокуляции и раииональное соотношение между FD и Lа5 в составе заквасочных композиций непосредственного внесения, которая составляэт 1:1 при исходной кониентрации каждой культуры в сливках $1 \cdot 10^{6} \mathrm{KOE} /$ см$^{3}$. Установлень параметры процесса ферментации и физического созревания сливок при сочетании заквасочных культур FD и La-5 в весенне-летний период года: температура ферментации $(30 \pm 1)^{\circ} \mathrm{C}$, продолжительность 4 ч; температура физического созревания (5 \pm 1$)^{\circ} \mathrm{C}$, продолжительность 6 ч.

Ключевые слова: кислосливочное масло, Flora Danica, L. acidophilus La-5, технология, ферментация, физическое созревание.

\title{
Study of the cream fermentation and physical maturation in the spring-summer period under the production of butter with probiotic properties
}

\author{
L.Y. Musiy, O.Y. Tsisaryk \\ musiyluba@ukr.net, tsisaryk_o@yaoo.com \\ Lviv National University of Veterinary Medicine and Biotechnologies named after S.Z. Gzhytskyi, \\ Pekarska Str., 50, Lviv, 79010, Ukraine
}

\begin{abstract}
The aim of our research was to establish the optimal parameters of the cream fermentation and physical maturation under the production of cultured butter in the spring-summer period with the combination of mesophilic cultures Flora Danica (FD) - Lactococcus lactis ssp. cremoris, Lactococcus lactis ssp. lactis, Leuconostoc mesenteroides ssp. cremoris, Lactococcus lactis ssp. diacetylactis with thermophilic monocultures of Lactobacillus acidophilus probiotic strain La-5 (La-5). Cultured butter of four groups were made: I group (samples KL1, KL2, KL3 under the using FD; $F D+L a-5$; La-5 respectively) - cream for fermentation temperature $(30 \pm 1){ }^{\circ} \mathrm{C}$; II (samples KL4, KL5, KL6 under the using $F D ; F D+L a-5$; La-5, respectively) - cream for fermentation temperature $(37 \pm 1){ }^{\circ} \mathrm{C}$; III (samples KL7, KL8, KL9 under the using FD; FD+La-5; La-5 respectively) - summer Danish stepwise regime; IV (KL10, KL11, KL12 under the using FD, FD+La-5, La-5, respectively) - adding starters into butter grain. Acid activity were controlled in fermented cream and in butter plasma.

The possibility of a combination FD mesophilic cultures with thermophilic monoculture L. acidophilus probiotic strains La-5 in the cream under the production of cultured butter with probiotic properties. Dose and ratio inoculation between FD and La-5 starter were experimentally found - 1:1 at the initial concentration of each culture in cream $110^{6} \mathrm{cfu} / \mathrm{cm}^{3}$ for the production of cultured butter with probiotic properties. The parameters of the fermentation process and the physical maturation of the cream for combination starter cultures FD and La-5 in the spring-summer season are: fermentation temperature $(30 \pm 1){ }^{\circ} \mathrm{C}$, the duration of 4 hours; physical ripening temperature $(5 \pm 1){ }^{\circ} \mathrm{C}$, duration 6 hours. Cultured butter characterized excellent taste and aroma uder the optimal fermentation temperature and physical maturation of the cream.
\end{abstract}

Key words: cultured butter, Flora Danica, L. acidophilus La-5, technology, fermentation, physical maturation.

\section{Вступ}

Вершковому маслу, якому тривалий час несправедливо приписували властивості шкідливого впливу на здоров'я людини, в останні роки приділяють особливу увагу. Перегляду ролі вершкового масла у дієті людини, в тому числі й літнього віку, слугувало відкриття унікальних біологічних властивостей деяких жирних кислот, характерних тільки для молочного жиру жуйних тварин, особливо транс-11 ізомерів лінолевої та олеїнової, а також коротколанцюгових і розгалужених жирних кислот. Додаткових цінних властивостей кисловершковому маслу можна надати завдяки використанню пробіотичної молочнокислої культури та можливості моделювання жирнокислотного складу, насамперед, збільшення транс-11 позиційних ізомерів ненасичених жирних кислот. Про можливий синтез транс-11 ізомерів молочнокислими бактеріями повідомляється в літературі (Jiang et al., 1998; Ogawa et al., 2005; Domagala et al., 2009; Mohan et al., 2013), однак це стосується кисломолочних напоїв, а щодо утворення цих ізомерів під час ферментації вершків літературні дані відсутні. Значний внесок у розробку теоретичних і практичних основ виробництва кисловершкового масла зробили вітчизняні та закордонні вчені: Д.В. Качераускіс (1968), В.М. Лазаускас (1977), А. Люткевичюс (1980), А.Д. Грищенко (1983), Ф.А. Вишемирський (1987), О.В. Боднарчук (2010),
R.C. Lindsay (1965), S. Mallia (2008) та ін., однак технологія кисловершкового масла 3 пробіотичними властивостями потребує наукового обгрунтування.

Кисловершкове масло - це масло, яке характеризується багатим смако-ароматичним букетом, якого надають йому молочна кислота і ароматичні речовини (діацетил і леткі органічні кислоти), що утворюються при збродженні молочного цукру молочнокислими бактеріями (Vyshemyrskyj, 2006; Musij and Cisaryk, 2011). Наявність цих метаболітів молочнокислих бактерій у кисловершковому маслі має важливе значення для підвищення його функціональної цінності порівняно $з$ іншими видами масла і для збільшення термінів придатності до споживання (Mallia et al., 2008; Macciola et al., 2008). Молочна кислота та діацетил проявляють антибактеріальну активність щодо сторонньої мікрофлори - інгібують розвиток гнильних бактерій, ріст Escherichia coli, Staphylococcus aureus, Salmonella (Lanciotti and Patrignani, 2003). Водночас кисловершкове масло є джерелом цілого ряду корисних речовин завдяки високому вмісту молочного жиру (Vyshemyrskyj, 2008).

Кисловершкове масло є досить популярним продуктом у європейських країнах, на відміну від нашої держави. У практиці вітчизняного маслоробства кисловершкове масло представлене лише марками «President» (група «Лакталіс») та «Преміум» (група «КОМО») із використанням іноземних заквашуваль- 
них культур. Причиною низького попиту кисловершкового масла в Україні є не лише розбіжності між смаками споживачів, але й суперечливі питання у особливостях технології виробництва, непристосованість режимів технологій до відмінностей складу та властивостей вітчизняної сировини, що унеможливлює виробництво продукту відповідно до існуючих вимог показників якості (Rozhanska et al., 2011). Це, у свою чергу, викликало інтерес до відродження технології кисловершкового масла.

Для виробництва кисловершкового масла 3 пробіотичними властивостями нами було запропоновано дві культури (фірми Chr. Hansen, Данія): мезофільну ароматичну культуру Flora Danica (містить змішані культури Lac. lactis ssp. cremoris, Lac. lactis ssp. lactis, Leu. mesenteroides ssp. cremoris, Lac. lactis ssp. diacetylactis) та пробіотичну культуру L. acidophilus штам $L a-5$.

Штам $L a-5$ - це штам, аналогічний тому, що знаходиться в кишечнику людини. $L a-5$ характеризується високою стійкістю до соляної та молочної кислот протягом тривалого контакту з ними, що можна вважати гарантом збереження їх життєздатності при транзиті через кисле середовище шлунка та при зберіганні кисломолочних продуктів (Didux et al., 2008).

Підтримання високого рівня життєздатної кількості клітин пробіотика у ферментованих харчових продуктах під час зберігання $\epsilon$ не простим завданням. На життєздатність культур впливає: кислотність продукту, взаємодія заквашувальних культур між собою та умови зберігання (Gilliland et al., 2002). Проте, є декілька повідомлень, що наявні у продажі молочні продукти містять недостатню кількість життєздатних клітин пробіотика (до $<10^{6}$ КУО/г на кінець терміну зберігання), тим самим зменшуючи позитивний вплив на здоров'я людини (Tharmaraj and Shah, 2003). Таким чином, виживання пробіотиків і розроблення методів для підтримки їх життєдіяльності протягом усього терміну зберігання $\epsilon$ важливим предметом досліджень.

У наш час у різних країнах світу L. acidophilus вводять у молочну сировину як монокультуру, так і у комплексі з різноманітними видами молочнокислих бактерій для виробництва кисломолочних продуктів (Kaushal and Kansal, 2014). Доведено можливість і доцільність спільного культивування мезофільних молочнокислих лактококів і ацидофільної палички (Dianawati et al., 2013), що дозволяє одержати у продукті досить високу концентрацію життєздатних клітин обох груп мікроорганізмів. Зокрема, розроблений ферментований молочний продукт 3 використанням культур L. acidophilus La-5, L. casei 431, BВ-12 та Flora Danica. Найкращою життєздатною властивістю під час зберігання за температури $+4{ }^{\circ} \mathrm{C}$ характеризувався варіант за поєднання L. acidophilus $L a-5$ із змішаними культурами Flora Danica (Paraschiv et al., 2011). Ферментативним середовищем для таких продуктів слугувало молоко. Однак вершки відрізняються за хімічним складом від молока значно вищим вмістом жиру, що проявляє бактеріостатичні властивості, а також меншим вмістом лактози, як субстрату для бродіння та меншим вмістом ростових факторів, що ускладнює перебіг процесу ферментації.
Тому метою досліджень було встановити та обгрунтувати оптимальні параметри ферментації та фізичного визрівання вершків при виробництві кисловершкового масла у весняно-літній період року за поєднання класичних для масла змішаних мезофільних культур Flora Danica (FD) - Lactococcus lactis ssp. cremoris, Lactococcus lactis ssp. lactis, Leuconostoc mesenteroides ssp. cremoris, Lactococcus lactis ssp. diacetylactis iз термофільною монокультурою Lactobacillus acidophilus пробіотичного итаму La-5 $(L a-5)$. Для досягнення мети були поставлені такі завдання:

- встановити можливість поєднання $F D$ iз $L a-5$ для ферментації вершків та визначити оптимальну іiі температуру за такого поєднання;

- встановити дозу інокуляції $L a-5$ для надання продуктові пробіотичних властивостей;

- обгрунтувати та встановити технологічні параметри ферментації і фізичного визрівання вершків при виробництві кисловершкового масла за поєднання $F D$ і $L a-5$ у весняно-літній період року.

\section{Матеріал та методи досліджень}

Оскільки склад та властивості молочного жиру icтотно відрізняються залежно від періоду року, нами розроблено технологію кисловершкового масла у весняно-літній період року. Експериментальні дослідження було проведено у кінці серпня на початку вересня 2013 р. Молоко піддавали сепаруванню за температури $40 \ldots 45^{\circ} \mathrm{C}$. Отримані вершки з масовою часткою жиру $33 \%$ пастеризували за температури $95^{\circ} \mathrm{C}$ без витримування, після пастеризації вершки охолоджували до температури ферментації. Для заквашування вершків використовували ліофілізовану мезофільну культуру безпосереднього внесення $F D$ самостійно (вихідна концентрація $1 \cdot 10^{6} \mathrm{KУO} / \mathrm{cm}^{3}$ ); поєднання $F D$ з пробіотичною монокультурою $L a-5$ (співвідношення культур - 1:1 при вихідній концентрації у вершках $1 \cdot 10^{6} \mathrm{i} 1 \cdot 10^{6} \mathrm{KУО} / \mathrm{cm}^{3}$ відповідно) та $L a-5$ самостійно (вихідна концентрація $\left.1 \cdot 10^{6} \mathrm{KУO} / \mathrm{cm}^{3}\right)$.

3 урахуванням особливостей культивування заквашувальних культур за різних температур та технології виробництва кисловершкового масла у веснянолітній період року було виготовлено чотири групи масла для досліджень:

I група (зразки 1 - КЛ1, 2 - КЛ2, 3 - КЛ3 при заквашуванні вершків $F D, F D+L a-5 ; L a-5$ відповідно) - ферментація вершків за температури $(30 \pm 1)^{\circ} \mathrm{C}$ та фізичне визрівання за температури $(5 \pm 1){ }^{\circ} \mathrm{C}$;

II група (зразки 4 - КЛ4, 5 - КЛ5, 6 - КЛ6 при заквашуванні вершків $F D, F D+L a-5, L a-5$ відповідно) - ферментація вершків за температури $(37 \pm 1)^{\circ} \mathrm{C}$ та фізичне визрівання за температури $(5 \pm 1){ }^{\circ} \mathrm{C}$;

III група (зразки 7 - КЛ7, 8 - КЛ8, 9 - КЛ9 при заквашуванні вершків $F D, F D+L a-5, L a-5$ відповідно) - $(20 \pm 1)^{\circ} \mathrm{C} \rightarrow(6 \pm 1)^{\circ} \mathrm{C} \rightarrow(10 \pm 1)^{\circ} \mathrm{C}$ - літній ступеневий режим аналогічний данському;

IV група (зразки 10 - КЛ10, 11 - КЛ11, 12 - КЛ12 при заквашуванні $F D, F D+L a-5, L a-5$ відповідно) внесення заквашувальних культур у масляне зерно. 
Вихідна концентрація клітин при інокуляції масляного зерна $-1 \cdot 10^{8} \mathrm{KУО} / \mathrm{cm}^{3}$. Зразки КЛ10...КЛ12 витримували за температури $(9 \pm 1)^{\circ} \mathrm{C}$ протягом 3 діб для наростання кислотності.

У заквашених вершках контролювали активність кислотоутворення за зміною титрованої і активної кислотності. Титровану кислотність плазми масла розраховували за формулою:

$$
K_{\Pi}=\left(K_{\text {вер }} / 100-Ж_{\text {вер }}\right) \cdot 100,
$$

де, $\mathrm{K}_{\text {П }}$ - титрована кислотність плазми масла, ${ }^{\circ} \mathrm{T}$;

$\mathrm{K}_{\text {вер }}$ - титрована кислотність вершків перед збиванням у масло, ${ }^{\circ} \mathrm{T}$;

$Ж_{\text {вер }}$ - масова частка жиру у вершках, \%.

Органолептичні властивості зразків виготовленого масла оцінювали за 17-бальною шкалою (смак і запах - 10 балів, колір - 2, консистенція -5).

\section{Результати та їх обговорення}

Органолептичні та фізико-хімічні показники масла залежать, у першу чергу, від жирнокислотного складу ліпідів, режимів виробництва та зберігання готового продукту. В Україні виділяють два періоди року, протягом яких спостерігаються зміни складу і властивостей молочного жиру: це травень-жовтень (йодне число вище 34,5 одиниць) та листопад-квітень (йодне число нижче 34,5 одиниць) (Grushhenko, 1983). Для

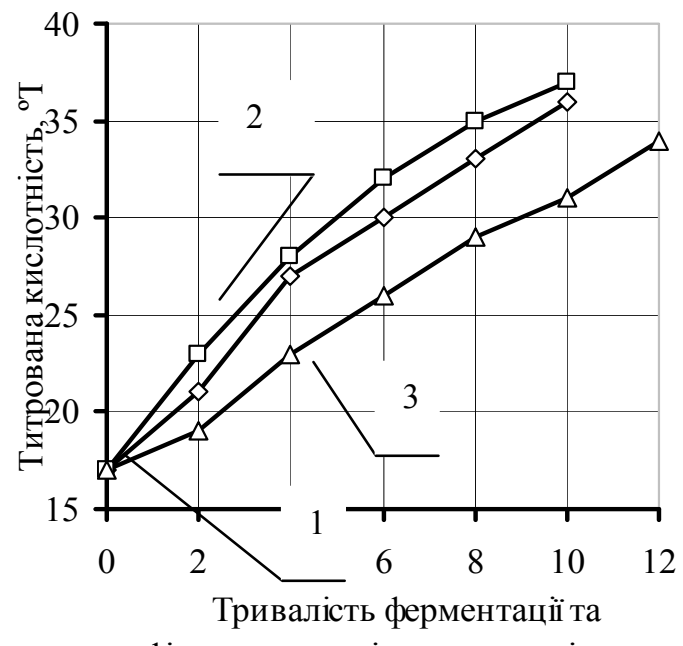

фізичного визрівання вершків, год.

a) цих періодів року встановлюються диференційовані режими виробництва масла.

Щодо виробництва кисло вершкового масла, то ключовими критеріями оцінки перспективності використання того чи іншого штаму як складової бактеріальних композицій $є$ продукування ним молочної кислоти у кількості, достатній для забезпечення бажаного рівня титрованої кислотності у плазмі та/або активний синтез смако-ароматичних сполук. Кислотності плазми вершків $55^{\circ} \mathrm{T}$ можна досягти забезпеченням відповідних умов для заквашувальної композиції.

Активність кислотоутворення у заквашених вершках контролювали за зміною титрованої та активної (од. $\mathrm{pH}$ ) кислотності.

При заквашуванні вершків заквашувальними композиціями $F D$ і $L a-5$ при температурі $(30 \pm 1)^{\circ} \mathrm{C}$, ферментація у зразках КЛ1...КЛ2 тривала 4 год., у зразку КЛ3 - 6 год. (рис. 1, а, б); за цей час активна кислотність вершкового згустку через 4 год. для зразків КЛ1 і КЛ2 сягла 5,91 і 5,85 од. $\mathrm{pH}$ відповідно, а для зразка КЛ3 через 8 год. - 5,92 од. рН. Протягом перших двох годин ферментації триває лаг-фаза, впродовж якої рівень рН у зразку КЛЗ знизився незначно. Тривалість ферментації та фізичного визрівання вершків для зразків КЛ1 і КЛ2 становила 10 год., для зразка КЛ3 - 12 год. Титрована кислотність вершків у кінці фізичного визрівання для зразків КЛ1, КЛ2 і КЛ3 дорівнювала 36,37 і $34^{\circ}$ Т відповідно.

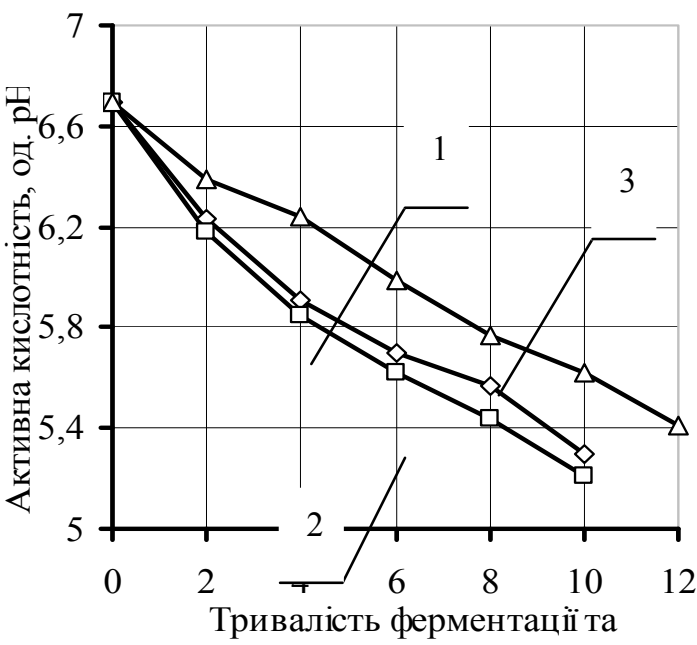

фізичного визрівання вершків, год.

б)

Рис. 1. Зміна титрованої (а), активної (б) кислотності вершків при ферментації за температури (30 \pm 1$){ }^{\circ} \mathrm{C}$ та фізичного визрівання за температури (5 \pm 1$)^{\circ} \mathrm{C}: 1,2$ і 3 - КЛ1, КЛ2 і КЛ3 відповідно

Титрована кислотність вершків, заквашених заквашувальною композицією $F D+L a-5$, за температури $(37 \pm 1){ }^{\circ} \mathrm{C}$ у кінці ферментації становила $26^{\circ} \mathrm{T}$ (рис. 2, а, б). Такого рівня кислотності було досягнуто протягом 6 год. сквашування. Охолодження ферментованих вершків починали, коли титрована кислотність була на $8 \ldots 10^{\circ} \mathrm{C}(\mathrm{pH} 5,91 \ldots 5,72)$ меншою від потрібної. Загальна тривалість сквашування і фізичного визрівання вершків для зразків КЛ4...КЛ6 становила 12 год., протягом якого титрована кислотність для КЛ5 зросла на $19^{\circ}$ Т, для зразків КЛ4 і КЛ6 - на 18 і $19^{\circ}$ Т відповідно. Протягом ферментації та фізичного визрівання активна кислотність для зразків КЛ4, КЛ5 і КЛ6 зменшилася на 1,36, 1,4, 1,46 од. рН відповідно. 


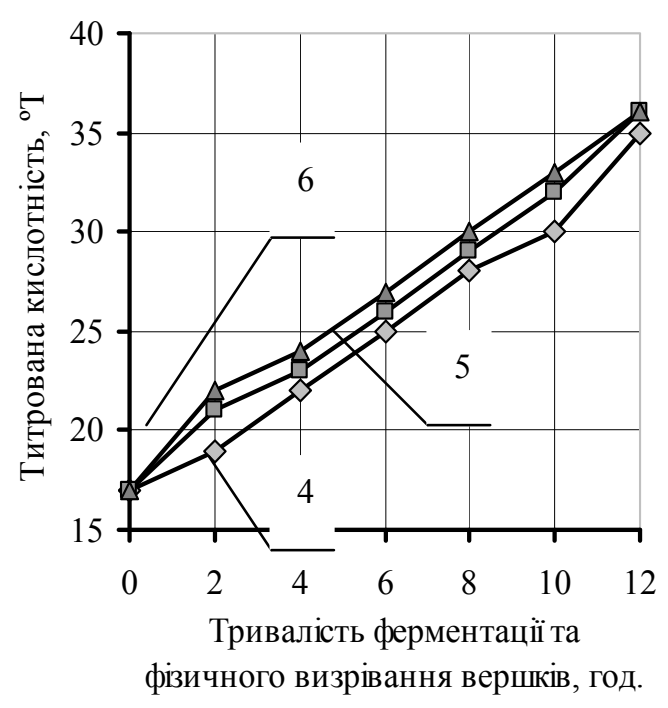

a)

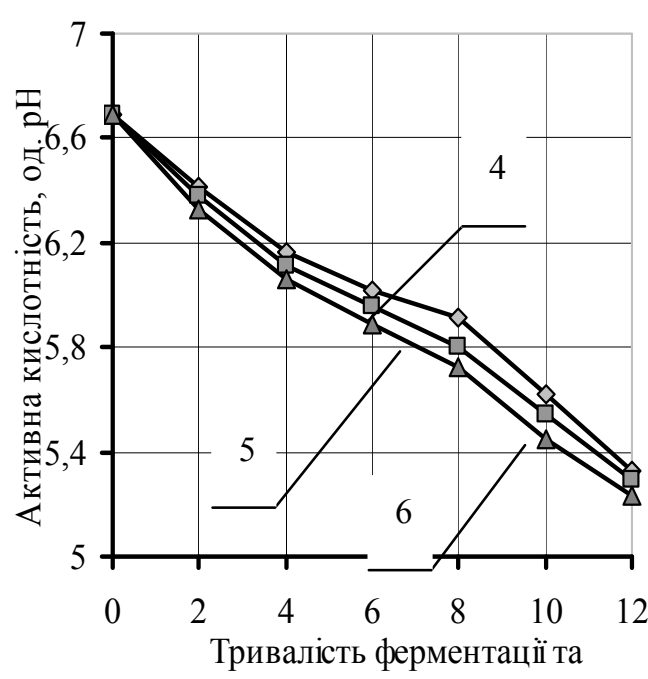

фізичного визрівання вершків, год.

б)

Рис. 2. Зміна титрованої (а), активної (б) кислотності вершків при ферментації за температури $(37 \pm 1)^{\circ} \mathrm{C}$ та фізичного визрівання за температури $(5 \pm 1)^{\circ} \mathrm{C}: 4,5$ i 6 - КЛ4, КЛ5 і КЛ6 відповідно

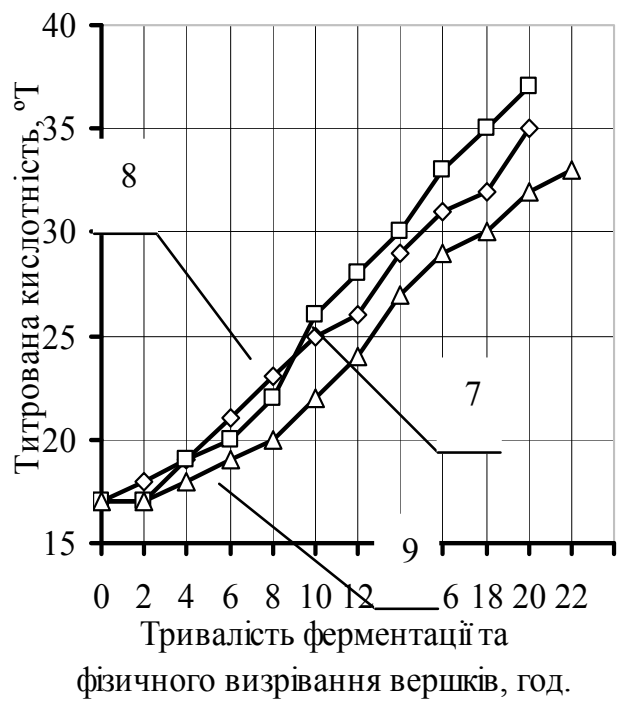

a)

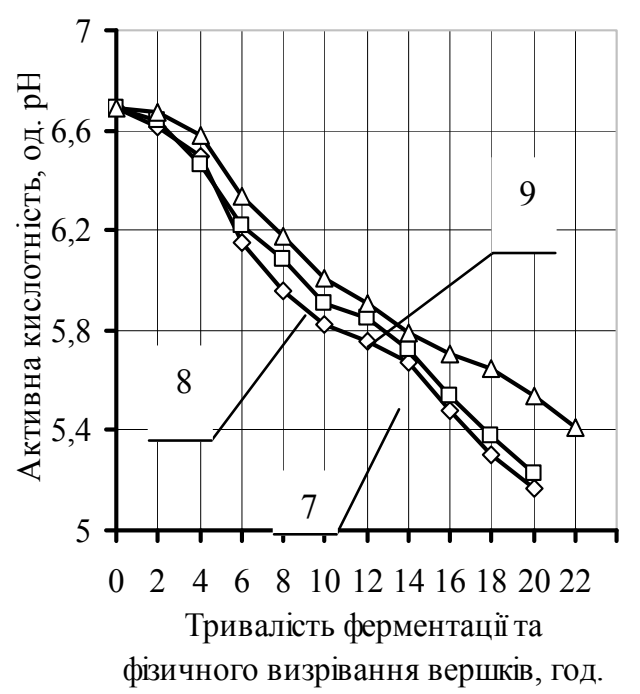

б)

Рис. 3. Зміна титрованої (а) та активної (б) кислотності вершків: ферментація за температури $(20 \pm 1)^{\circ} \mathrm{C} \mathbf{~}$ фізичне визрівання за температури $(6 \pm 1)^{\circ} \mathrm{C} ; 7,8$ і 9 - КЛ7, КЛ8 і КЛ9 відповідно

При застосуванні літнього ступеневого температурного режиму $20 \pm 1{ }^{\circ} \mathrm{C} \rightarrow 6 \pm 1{ }^{\circ} \mathrm{C} \rightarrow 12 \pm 1{ }^{\circ} \mathrm{C}$ тривалість біологічного сквашування і фізичного визрівання вершків становила для зразків КЛ7 і КЛ8 понад 20 год., для КЛ9 - 22 год. (рис. 3), а для зразків КЛЗ...КЛ6 - 12 год.

Подовження тривалості ферментації для КЛ9 є результатом занижених температур розвитку для термофільної $L a-5$, що засвідчується найповільнішим наростанням титрованої кислотності. Титрована кислотність вершків у зразку КЛ8 досягла значення $37^{\circ} \mathrm{T}$ за 20 год. (рис. 3, а), тоді як у зразку КЛ2 - за 10 год. У зразку КЛ9 титрована кислотність у кінці фізичного визрівання становила $33^{\circ} \mathrm{T}$, що відповідало 5,41 од. $\mathrm{pH}$. Таке значення титрованої та активної кислотності у подальшому може відобразитись на кількості життєздатних клітин $L a-5$ у кисловершковому маслі. У зразках КЛ7...КЛ9 активна кислотність вершків перед збивання у масло була у межах $5,41 \ldots 5,17$ од. $\mathrm{pH}$ (рис. 3, б).

Отже, результати проведених досліджень свідчать про кращі температурні умови $(30 \pm 1)$ та $(37 \pm 1){ }^{\circ} \mathrm{C}$ для спільного культивування $F D$ та $L a-5$.

Титрована кислотність плазми масла лінійно залежить від кислотності вершків перед збиванням. Найвищими показниками кислотності плазми $\left(54,4{ }^{\circ} \mathrm{T}\right)$ характеризувались зразки КЛ2 та КЛ8, для сквашування вершків яких застосовували поєднання $F D$ та $L a-5$ за температури ферментації $(30 \pm 1)$ та $(20 \pm$ 1) ${ }^{\circ} \mathrm{C}$ (табл. 1). Другу позицію за кислотністю плазми займали зразки КЛ2 та КЛ5 - 52,9 ${ }^{\circ} \mathrm{T}$, при кислотності вершків $36^{\circ} \mathrm{T}$. Найнижчими показниками титрованої 
кислотності плазми характеризувалися зразки КЛ3, КЛ9...КЛ12, оскільки активність кислотоутворення у цих зразках була найменша. Зразки КЛ10...КЛ12 виготовляли внесенням заквашувальних культур у масляне зерно: $F D(10-$ КЛ10), поєднанням $F D+L a-$ 5 (11 - КЛ11) та $L a-5$ (12 - КЛ12); інокуляція культур $1 \cdot 10^{8} \mathrm{KУO} / \mathrm{cm}^{3}$. Для формування необхідно рівня титрованої кислотності зразки дозрівали за температури $(9 \pm 1)^{\circ} \mathrm{C}$ протягом 3 діб. Після витримування (на
4 добу) титрована кислотність плазми масла для зразка КЛ10 становила $-42^{\circ} \mathrm{T}$, для КЛ11 - 36 ${ }^{\circ} \mathrm{T}$, для КЛ12 - $35^{\circ} \mathrm{T}$. Така титрована кислотність плазми впливає на редукцію смако-ароматичних речовин у маслі і може впливати на розвиток сторонньої мікрофлори. Використання активного кислотоутворювача $F D$ та операції сквашування вершків зумовило підвищення кислотності плазми з 25,0 до 48,5...54,4 ${ }^{\circ} \mathrm{T}$ у зразках кисловершкового масла.

Табличя 1

Титрована кислотність плазми дослідних зразків кисловершкового масла (n=3)

\begin{tabular}{|c|c|c|c|c|c|c|c|c|c|c|c|c|}
\hline $\begin{array}{c}\text { Найменування } \\
\text { показника }\end{array}$ & КЛ1 & КЛ2 & КЛ3 & КЛ4 & КЛ5 & КЛ6 & КЛ7 & КЛ8 & КЛ9 & КЛ10 & КЛ11 & КЛ12 \\
\hline $\begin{array}{c}\text { Кислотність } \\
\text { плазми масла, } \\
\text { o } \mathrm{T}\end{array}$ & 52,9 & 54,4 & 50,0 & 51,5 & 52,9 & 52,9 & 51,5 & 54,4 & 48,5 & 42,0 & 36,0 & 35,0 \\
\hline
\end{tabular}

Залежно від складу заквашувальної композиції та температури ферментації вершків формуються органолептичні показники кисловершкового масла. За смаком і ароматом максимальну кількість балів отримав зразок КЛ1 (10 балів із максимальних 10). Другу позицію зайняли зразки КЛ2 і КЛ5 (9 балів). Зразки, для сквашування яких використовували $F D$ при температурі $(37 \pm 1){ }^{\circ} \mathrm{C}$ отримали 8 балів. Меншу кількість балів отримали решта зразків кисловершкового масла. Найменшу кількість балів за смаком і запахом отримали зразки КЛ9 і КЛ12 - 6 балів, що зумовлено низьким значенням титрованої та активної кислотності і несприятливими умовами для розвитку $L a-5$.

Таким чином, 3 огляду на тривалість ферментації і фізичного визрівання вершків, а також на кислотність плазми масла перспективною для розроблення технології кисловершкового масла 3 пробіотичними властивостями у весняно-літній період року є заквашувальна композиція $F D$ у поєднанні з L. acidophilus $L a-5$.

\section{Висновки}

1. Встановлено можливість поєднання класичних змішаних мезофільних культур $F D$ з термофільною монокультурою L. acidophilus La-5 для ферментації вершків у технології кисловершкового масла 3 пробіотичними властивостями.

2. Експериментально встановлено і науково обгрунтовано параметри процесу ферментації вершків: використання заквашувальної композиції $F D$ та $L a-5$ у співвідношенні 1:1 при вихідній концентрації кожної культури у вершках $1 \cdot 10^{6} \mathrm{KУО} / \mathrm{cm}^{3}$, температура ферментації $(30 \pm 1)^{\circ} \mathrm{C}$, тривалість 4 год.

3. Експериментально встановлено і науково обгрунтовано параметри процесу фізичного визрівання вершків у весняно-літній період року - температура $(5 \pm 1){ }^{\circ} \mathrm{C}$, тривалість 6 год.

4. За встановленої оптимальної температури ферментації і фізичного визрівання вершків кисловершкове масло характеризувалося найкращим смаком та ароматом.

Перспективи подальших досліджень. Подальшими нашими дослідженнями було встановити вплив заквашувальних культур безпосереднього внесення $F D$ і $L a-5$ на жирнокислотний склад ліпідів масла, вміст смако-ароматичних речовин, реологічні та антиоксидантні властивості масла, а також проаналізувати збереження пробіотичних властивостей кисловершкового масла при зберіганні.

\section{Бібліографічні посилання}

Mohan, M.S., Anand, S., Kalscheur, K.F., Hassan, A.N., Hippen, A.R. (2013). Starter cultures and cattle feed manipulation enhance conjugated linoleic acid concentrations in Cheddar cheese. Journal of Dairy Science, 96, 4, 2081-2094.

Domagala, J., Sady, M., Najgebauer-Lejko, D., Czernicka, M., Wieteska, I. (2009). The content of conjugated linoleic acid (CLA) in cream fermented using different starter cultures. Biotechnology in Animal Husbandry, $25,(5-6), 745-751$.

Ogawa, J., Kishino, S., Ando, A., Sugimoto, S., Mihara, K., Shimizu, S. (2005). Production of conjugated fatty acids by lactic acid bacteria. Journal of Bioscience and Bioengineering, 100, 355-364.

Jiang, J., Bjorck, L., Fonden, R. (1998). Production of conjugated linoleic acid by dairy starter cultures. Journal of Applied Microbiology, 85, 95-102.

Vyshemyrskyj, F.A. (2006). Maslo yz «vershkov». Syrodelye y maslodelye, 1, 25-28 (in Russian).

Musij, L.Y., Cisaryk, O.J. (2011). Osoblyvosti texnologiyi kyslovershkovogo masla. Naukovyj visnyk LNUVMBT imeni S.Z. Gzhyczkogo, 13, 4, 4 (50), 99-105 (in Ukrainian).

Mallia, S., Escher, F., Schlichtherle-Cerny, H. (2008). Aroma-active compounds of butter: a review. European Food Research and Technology, 226, 315325.

Macciola, V., Candella, G., Leonardis, A. (2008). Rapid gas-chromatographic method for the determination of diacetyl in milk, fermented milk and butter. Food control, 19, 9, 873-878.

Lanciotti, R., Patrignani, F. (2003). Evaluation of diacetyl antimicrobial activity against Escherichia coli, Listeria monocytogenesand Staphylococcus aureus. Food Microbiology, 5, 537-543.

Vyshemyrskyj, F.A. (2008). Etyudu o masle, maslodelyy y maslodelax. Molochnaya promushlennost, 36 (in Russian). 
Rozhanska, O.M., Bodnarchuk, O.V., Korol, O.V., Chorna, N.A., Kigel, N.F. (2011). Konstruyuvannya bakterialnyx kompozycij dlya vyrobnycztva kyslovershkovogo masla. Naukovyj visnyk LNUVMBT imeni S.Z. Gzhyczkogo, 13, 2(48), 372380 (in Ukrainian).

Didux, N.A., Chagarovsky, O.P., Lysogor, T.A. (2008). Zakvashuvalni kompozyciyi dlya vyrobnycztva molochnyx produktiv funkcionalnogo pryznachennya. Odesa: Poligraf (in Ukrainian).

Gilliland, S.E., Reilly, S.S., Kim, G.B., Kim, H.S. (2002). Viability During Storage of Selected Probiotic Lactobacilli and Bifidobacteria in a Yogurt-like Product. Journal of Food Science, 67, 3091-3095.

Tharmaraj, N., Shah, N.P. (2003). Selective Enumeration of Lactobacillus delbrueckii ssp. bulgaricus, Streptococcus thermophilus, Lactobacillus acidophilus, Bifidobacteria, Lactobacillus casei, Lactobacillus rhamnosus, and ropionibacteria. Journal of Dairy Science, 86, 2288-2296.
Kaushal, D., Kansal, V.K. (2014). Dahi containing Lactobacillus acidophilus and Bifidobacterium bifidum improves phagocytic potential of macrophages in aged Food Sci Technol., 51(6), 11471153.

Dianawati, D., Vijay, M., Shah Nagendra, P. (2013). Effect of drying methods of icroencapsulated Lactobacillus acidophilus and Lactococcus lactis ssp. cremoris on secondary protein structure and glass transition temperature as studied by Fourier transform infrared and differential scanning calorimetry. Journal of Dairy Science, 96, 1419-1430.

Paraschiv, D., Vasile, A., Constantin, M., Ciobanu, A., Bahrim, G. (2011). Study of physiological properties of some probiotics in multiple cultures with mesophilic lactis acid bacteria by Flora Danica $\mathrm{Ch}$. Hansen commercial starter. Food Technology, 35(2), 56-65.

Grushhenko, A.D. (1983). Slyvochnoe maslo. Legkaya y pyshhevaya promushlennost (in Russian).

Стаття надійшла до редакиії 15.09.2016 